\title{
Kualitas Hidup Remaja Berstatus Sosial Ekonomi Rendah: Bagaimana Kontribusi Resiliensi Keluarga?
}

\author{
Fathin Nazifa Ramadhanty, Melok Roro Kinanthi \\ Fakultas Psikologi, Universitas YARSI, Jl. Letjen Soeprapto, Jakarta Pusat, Indoensia \\ e-mail: melok.roro@yarsi.ac.id
}

\begin{abstract}
Adolescents from low socioeconomic status are prone to have poor quality of life. To gain optimal functioning, it is important to ensure they experience good quality of life. This study aims to examine whether family resilience affect quality of life among adolescent from low socioeconomic status in Jakarta. There were 130 participants in this quantitative study. Convenience sampling were applied to select participants. We used Indonesian version of WHOQoLBREF to assess quality of life and Walsh Family Resilience Questionnaire to assess family resilience. Data were analyzed by regression analysis and stated family resilience has significant positively contribution to quality of life among participants. For each dimension, the contribution of family resilience to quality of life was $7 \%$ to $16.4 \%$. It may indicate that family strength-based approach should be added in developing intervention to enhance quality of life among adolescents from low socioeconomic status in Jakarta.
\end{abstract}

Keywords: family resilience, quality of life, adolescent

\begin{abstract}
Abstrak
Remaja dengan status sosial ekonomi rendah rentan mengalami kualitas hidup yang buruk. Agar dapat berfungsi secara optimal, perlu dipastikan remaja menjalani hidup yang berkualitas baik. Penelitian ini bertujuan untuk mengetahui bagaimana kontribusi resiliensi keluarga terhadap kualitas hidup remaja berstatus sosial ekonomi rendah yang berdomisili di Jakarta. Partisipan dalam penelitian kuantitatif ini berjumlah 130 orang, yang ditentukan berdasarkan convenience sampling. Dalam penelitian ini, WHOQolBREF versi Indonesia merupakan alat ukur yang dipakai untuk mengukur variabel kualitas hidup, sementara untuk variabel resiliensi keluarga digunakan Walsh Family Resilience Questionnaire. Data penelitian ini dianalisis dengan menggunakan analisis regresi dan menemukan adanya peran resiliensi keluarga secara positif dan sigfnifikan terhadap kualitas hidup partisipan sebesar 7\%-16.4\%. Hal ini menunjukkan bahwa pendekatan berbasis penguatan keluarga dapat dipertimbangkan dalam penyusunan intervensi terhadap kualitas hidup remaja berstatus sosial ekonomi rendah.
\end{abstract}

Kata Kunci: resiliensi keluarga, kualitas hidup, remaja

\section{Pendahuluan}

Menurut data Badan Pusat Statistik (2019), jumlah penduduk dengan status sosial ekonomi rendah atau miskin di Jakarta berjumlah sekitar 365 ribu orang. Status sosial ekonomi rendah berhubungan dengan kualitas hidup yang rendah (Minooei dkk., 2016), yang menyangkut kesehatan fisik, psikologis, hubungan sosial dan lingkungan. Sebagai bagian dari populasi warga miskin kota, remaja yang berasal dari keluarga berstatus sosial ekonomi rendah lebih rentan mengalami kualitas hidup yang buruk dibanding kelompok usia lainnya. Secara umum kualitas hidup remaja cenderung mengalami penurunan (Petito \& Cummins, 2000), mengingat masa remaja merupakan masa-masa sulit karena adanya tekanan yang ditimbulkan oleh pubertas, peer group, atau perubahan dalam relasi keluarga (Steinberg, 1993, dalam Petito \& Cummins, 2000). Kondisi status sosial ekonomi yang rendah semakin memperbesar kerentanan remaja terhadap memburuknya kualitas hidup. 
Fenomena rendahnya kualitas hidup remaja dengan status sosial ekonomi rendah pada aspek kesehatan fisik, psikologis, relasi sosial maupun lingkungan dapat diihat dari berbagai temuan penelitian sebelumnya. Dari aspek kesehatan fisik, remaja dengan status sosial ekonomi rendah cenderung mengalami penyakit kronis, rentan mengalami kematian, merokok, minum alkohol, sulit mengakses layanan kesehatan, (Newacheck dkk., 2003; Liputo, 2014; Suparto, 2014; Restiyani dkk., 2013).

Pada aspek psikologis, remaja yang berasal dari keluarga dengan status sosial ekonomi rendah lebih sering mengalami masalah kesehatan mental dibandingkan remaja yang tidak miskin dan juga memiliki kesejahteraan psikologis yang rendah (Kim \& Hagquist, 2018; Shek \& Tsui, 2012). Peneliti lain mengidentifikasikan sejumlah hasil penelitian yang menunjukkan kemiskinan memiliki kaitan dengan masalah sosioemosional, depresi, kecemasan, dan masalah akademik (Taylor, 2010).

Pada aspek relasi sosial, Caron (2012) mengidentifikasikan kemiskinan meningkatkan risiko terhadap rendahnya kualitas hidup dalam dimensi sosial. Secara lebih spesifik, Shek dan Tsui (2012) mengidentifikasikan adanya masalahmasalah sosial yang dialami remaja dengan status sosial ekonomi rendah, yakni kenakalan remaja, konflik dengan orang tua, tekanan dari teman sebaya yang berperilaku menyimpang, putus sekolah, tidak disukai teman, serta menjadi korban atau pelaku perundungan (Shek \& Tsui, 2012; Gibb dkk., 2016).

Kualitas hidup yang baik akan membuat individu memiliki mental yang sehat (Caron, 2012). Mengingat remaja nantinya akan memasuki usia produktif dan menjadi generasi penerus bangsa, maka dari itu perlu dipastikan remaja mempunyai kualitas hidup yang optimal agar dapat menjalankan tugas perkembangannya dengan baik. Dengan demikian, penelitian mengenai faktor-faktor apa saja yang berkontribusi pada kualitas hidup remaja dengan status sosial ekonomi rendah perlu dilakukan.

WHOQoL mengemukakan kualitas hidup merupakan evaluasi individu mengenai kondisi hidupnya, dalam konteks budaya dan sistem nilai dimana ia berada, yang berhubungan dengan tujuan, harapan, standar, serta apa yang menjadi perhatian individu (Chachamovich dkk., 2010). Menurut WHOQoL, terdapat beberapa dimensi kualitas hidup yakni dimensi kesehatan fisik, psikologis, relasi sosial, dan lingkungan (Adeyeye dkk., 2014). Dimensi kesehatan fisik terkait kemampuan individu untuk melakukan rutinitas seharihari, penggunaan obat dan alat medis, vitalitas dan keletihan, pergerakan, rasa sakit dan ketidaknyamanan, serta kinerja. Dimensi psikologis terkait dengan kondisi mental seseorang. Dimensi relasi sosial terkait dengan hubungan individu dengan orang lain yang meliputi relasi personal, dukungan dari lingkungan sekitar, dan perilaku seksual. Dimensi lingkungan terkait dengan tempat tinggal seseorang, yaitu situasi, ketersediaan hunian untuk melakukan aktivitas, dan fasilitas yang dapat membantu kehidupan (Adeyeye dkk., 2014).

Hasil penelitian mengenai gambaran kualitas hidup pada individu dengan status sosial ekonomi rendah menunjukkan hasil yang kontradiktif (Aisyah \& Listiyandini, 2015). Penelitian pada remaja sosial ekonomi rendah di Bangkok menunjukkan bahwa mayoritas partisipan penelitian (73.2\%) yang merupakan remaja yang tinggal di pemukiman kumuh memiliki kualitas hidup kategori rendah/ menengah (Somrongthong dkk., 2012, dalam Aisyah \& Listiyandini, 2015), sementara hasil penelitian Pradono (2009, dalam Aisyah \& Listiyandini, 2015) menemukan bahwa individu dengan status sosial ekonomi rendah yang ditelitinya mempersepsikan dirinya memiliki kualitas hidup yang baik. Perbedaan ini mengindikasikan bahwa, 
meski menghadapi situasi yang sama (kemiskinan), individu bisa saja memiliki kualitas hidup yang berbeda.

Bronfenbrenner (1979, dalam Gamayanti, 2014) mengemukakan interaksi antara individu dengan mikrosistemnya (atau lingkungan terdekatnya) merupakan hal yang krusial bagi perkembangan individu tersebut. Dengan demikian, keluarga sebagai mikrosistem terdekat, merupakan faktor yang berperan penting dalam kualitas hidup remaja. Status sosial ekonomi rendah dapat menimbulkan berbagai tantangan atau situasi menekan bagi kehidupan individu maupun keluarganya. Bagaimana keluarga mengelola atau mengatasi situasi sulit akan memengaruhi anggota-anggotanya dalam beradaptasi (Walsh, 2012). Keluarga yang mampu beradaptasi secara sehat dengan tantangan hidup atau situasi menekan dapat mengajarkan anggota keluarganya untuk memecahkan masalah dan menetapkan tujuan yang ingin dicapai (GrenwaldMayes, 2002). Dengan demikian, anggota keluarga dapat meminimalisir atau bahkan keluar dari dampak negatif yang ditimbulkan dari keadaan ekonomi, yang pada akhirnya akan berkontribusi pada pencapaian kualitas hidup.

Bagaimana keluarga beradaptasi dan mengatasi situasi sulit termasuk ke dalam kajian resiliensi keluarga. Resiliensi keluarga merupakan kapasitas keluarga untuk bangkit dan melenting dari situasi sulit, untuk menjadi lebih kuat dan berdaya (Walsh, 2012). Konsep resiliensi keluarga fokus pada potensi keluarga untuk memulihkan diri dan bertumbuh dari situasi sulit (Walsh, 2012). Hal yang sama juga disimpulkan oleh Huber dkk. (2010) yakni konsep resiliensi keluarga menekankan pada penyesuaian atau adaptasi keluarga terhadap situasi kehidupan yang menantang.

Secara umum, ketika menghadapi situasi yang menekan, keluarga yang resilien akan memaknai situasi dengan sudut pandang yang positif dan tetap memiliki harapan bahwa situasi akan membaik (Walsh, 2012). Mengingat keluarga berperan dalam transmisi nilai maupun kompetensi anggotanya, maka remaja yang tinggal dalam keluarga yang resilien akan mengembangkan pemaknaan dan harapan positif terhadap situasi menekan yang dialami. Dengan demikian, individu memiliki orientasi masa depan yang positif meski saat ini mengalami situasi yang menekan. Hasil penelitian Maguire dkk. (2018) menyebutkan orientasi yang positif terhadap masa depan dapat meningkatkan kualitas hidup dengan mendorong individu untuk aktif mencari solusi terhadap masalah yang dihadapi.

Secara spesifik, resiliensi keluarga dapat berkontribusi bagi setiap dimensi kualitas hidup. Pada dimensi fisik, keluarga yang resilien memungkinkan anggotanya untuk dapat beradaptasi secara sehat saat menghadapi tekanan (Greef \& Van Der Walt, 2010). Dengan demikian, ketika individu bebas dari tekanan atau stres maka daya tahan tubuh akan meningkat dan melindungi individu tersebut dari timbulnya penyakit (Khalil dkk., 2020). Selain itu, remaja dengan status ekonomi rendah rentan mengalami gizi buruk (Patty \& Nugroho, 2019) karena keterbatasan sumber daya untuk menyajikan makanan yang bergizi. Keluarga yang resilien akan mampu mencari solusi yang efektif untuk mengatasi persoalan tersebut.

Terkait dimensi kesehatan psikologis pada kualitas hidup, adanya resiliensi keluarga memungkinkan remaja untuk memperoleh kesejahteraan emosi (Cummins, dalam Petito \& Cummins, 2000). Hal ini dapat terjadi karena keluarga yang resilien memberikan kesempatan pada anggota keluarganya untuk mengungkapkan perasaan mereka secara terbuka, menerima ekspresi anggota keluarga dan merespon secara empatik (Walsh, 2012), termasuk saat menghadapi situasi sulit yang diakibatkan kondisi ekonomi. Selain itu, keluarga yang resilien merupakan keluarga yang memiliki relasi 
positif antar anggotanya (Walsh, 2012). Relasi keluarga yang positif ini dapat berkontribusi meningkatkan kualitas kesehatan mental individu, yang pada akhirnya meningkatkan kualitas hidup (Ali $\&$ Malik, 2015).

Terkait dimensi sosial pada kualitas hidup, keluarga yang resilien merupakan keluarga yang mampu mengelola dukungan yang disediakan oleh lingkungan sekelilingnya (Walsh, 2012). Kemampuan mengelola dukungan sosial ini termasuk bagaimana menjalin relasi sosial yang sehat dan sesuai ekspektasi masyarakat. Keluarga yang resilien akan mengajarkan anak bagaimana berinteraksi dan memelihara relasi sosial (Grenwald-Mayes, 2002). Dengan demikian, anak mengetahui dan cakap dalam membina hubungan sosial yang sehat dengan orang-orang di sekelilingnya. Kompetensi dalam mengembangkan relasi sosial ini memungkinkan anak untuk memperoleh dukungan sosial dari lingkungannya (non keluarga), yang mana adanya dukungan sosial ini dapat meningkatkan kualitas hidup (Cappe dkk., 2018), khususnya pada dimensi sosial.

Dimensi lingkungan pada kualitas hidup meliputi kondisi tempat tinggal individu, yaitu keadaan, ketersediaan tempat tinggal, serta adanya sarana dan prasarana yang dapat menunjang kehidupan (Adeyeye dkk., 2014). Secara umum keadaan lingkungan di sekitar tempat tinggal warga dengan status sosial ekonomi rendah tidak higienis, sanitasi kurang bersih, tidak sehat, dan kumuh (Aisyah \& Listiyandini, 2015). Keluarga yang resilien meyakini bahwa mereka memiliki efikasi diri dalam mengatasi masalah dan memiliki harapan bahwa situasi akan membaik (Huber dkk., 2010). Adanya harapan tersebut dapat memantik keluarga melakukan coping yang berfokus pada penyelesaian masalah, yakni meminimalisir risiko yang ditimbulkan oleh lingkungan sekitar yang tidak sehat tersebut dan mencari solusi agar kondisi lingkungan tempat tinggalnya menjadi lebih baik.

Penelitian-penelitian tentang kualitas hidup, baik di Indonesia maupun luar negeri, banyak dilakukan pada individu yang mengalami gangguan kesehatan fisik (Caliskan dkk., 2019; Lovie-Toon dkk., 2018; Archentari dkk., 2017; Yuwindry dkk., 2016; Nikmah \& Mauliza, 2018; Oktowaty dkk., 2018; Desnauli dkk., 2011; Rohmah dkk., 2012; Gamayanti \& Hidayat, 2019; Hidayat \& Gamayanti, 2020), sementara belum banyak penelitian yang menyasar populasi rentan lainnya, seperti kelompok status sosial ekonomi rendah. Selain itu, penelitian-penelitian sebelumnya di Indonesia cenderung berfokus pada modal psikologis personal sebagai faktor yang berkontribusi pada kualitas hidup seperti self compassion (Kawitri dkk., 2020) dan kebersyukuran (Wijayanti dkk., 2020; Hidayat \& Gamayanti, 2020).

Penelitian yang mengkorelasikan resiliensi dengan kualitas hidup telah dilakukan oleh Aisyah dan Listiyandini (2015), Pane dan Saragih (2020), serta Rachmawati dkk. (2019). Meski demikian, resiliensi yang diteliti dalam penelitian tersebut adalah resiliensi yang dimiliki secara individual, dan tidak mencerminkan gambaran resiliensi keluarga. Sementara, perkembangan individu tidak dapat dipisahkan dari peran lingkungan terdekatnya (mikrosistem), yakni keluarga. Penelitian ini akan mengkaji peran lingkungan terdekat remaja, yakni keluarga, terhadap kualitas hidup. Adapun penelitian sebelumnya di Indonesia yang mengkorelasikan resiliensi keluarga dan kualitas hidup telah dilakukan oleh Mufarrohah dan Kinanthi (2020). Meski demikian, penelitian tersebut dilakukan pada populasi yang berbeda dari penelitian ini, yakni individu yang berusia dewasa muda, dan bukan usia remaja.

Berdasarkan paparan sebelumnya, peneliti mengajukan hipotesis yakni terdapat peran yang signifikan dari resiliensi keluarga terhadap masing-masing 
dimensi kualitas hidup remaja berstatus sosial ekonomi rendah di Jakarta.

\section{Metode Penelitian}

Penelitian ini merupakan penelitian kuantitatif yang memakai desain non eksperimen dan bertipe kausalitas. Partisipan yang menjadi sasaran adalah 130 remaja berdomisili di Jakarta, yang memiliki keluarga berstatus sosial ekonomi rendah berdasarkan kriteria Badan Pusat Statistik (2019), yakni memiliki jumlah pengeluaran keluarga inti per bulan di bawah Rp 1.901.402. Mayoritas partisipan berjenis kelamin perempuan $(94 \%)$ dan berada dalam tahap usia remaja awal (76\%). Sebagian besar partisipan $(82 \%)$ memiliki kedua orang tua yang masih dalam status menikah (utuh, tidak bercerai, tidak meninggal dunia salah satunya), berpendidikan formal tingkat dasar (ibu, 57\%) dan menengah (ayah, 77\%). Partisipan didapatkan melalui teknik non probability sampling, yakni convenience sampling, artinya diperoleh berdasarkan ketersediaan dan kerelaan individu untuk berpartisipasi sebagai partisipan (Gravetter \& Forzano, 2015).

Sebelum melaksanakan penelitian, peneliti mengajukan kelayakan etik penelitian kepada Lembaga Penelitian Universitas YARSI. Setelah memperoleh surat kelayakan etik, peneliti melakukan pengambilan data di sekolah yang berada di Jakarta dan berlokasi di dekat pemukiman atau wilayah yang mayoritas penduduknya diperkirakan memiliki status sosial ekonomi rendah. Setelah memperoleh izin penelitian dari pihak sekolah, peneliti menyebarkan kuesioner kepada siswa-siswi di sekolah tersebut secara langsung tanpa melalui perantara pihak sekolah. Peneliti mengeliminasi kuesioner yang diiisi oleh partisipan yang tidak memenuhi karakteristik penelitian.

Variabel kualitas hidup diukur dengan WHOQoL BREF versi Indonesia yang telah diadaptasi oleh Purba dkk. (2018). WHOQoL BREF memiliki 26 butir pernyataan lapor diri, yang masing-masing memiliki opsi jawaban yakni tidak pernah, jarang, cukup sering, sangat sering, dan selalu (lima poin skala Likert, 1-5). WHOQoL BREF mempunyai lima dimensi, yakni dimensi kesehatan fisik (contoh item, "Seberapa sering Anda membutuhkan bantuan medis untuk dapat berfungsi di dalam kehidupan seharihari?"), dimensi psikologis (contoh item, "Seberapa sering Anda dapat menjalani hidup Anda sehari-hari dengan perasaan gembira?"), dimensi relasi sosial (contoh item, "Seberapa puaskah Anda dengan dukungan yang Anda peroleh dari teman Anda?"), dan dimensi lingkungan (contoh item, "Seberapa puaskah Anda dengan kondisi tempat tinggal Anda saat ini?"').

Dalam penelitian ini, koefisien reliabilitas yang dihasilkan oleh tiap-tiap dimensi WHOQoL BREF adalah .712 untuk dimensi kesehatan fisik, .755 untuk dimensi psikologis, .751 untuk dimensi relasi sosial, dan .847 untuk dimensi lingkungan. Adapun mayoritas item memiliki corrected item total correlation berkisar antara .239 - .680. Crocker dan Algina (dalam Azwar, 2016) menyatakan koefisien corrected item total correlation diatas .20 sudah dianggap memuaskan. Menimbang hal ini, dan juga koefisien reliabilitas yang diperoleh tiap dimensi WHOQoL BREF juga tergolong cukup memuaskan, maka peneliti tetap mengikutsertakan item-item dengan koefisien corrected item total correlation minimal .20.

Untuk mengukur persepsi partisipan mengenai resiliensi keluarganya, peneliti menggunakan Walsh Family Resilience Questionnaire atau WFRQ (Walsh, 2012). Terjemahan Bahasa Indonesia untuk instrumen ini mengacu pada terjemahan Wandasari (2012), yang mana terjemahan tersebut telah melalui expert judgement dan uji reliabilitas dalam penelitian Maulidia dkk. (2018). Terdapat 32 pernyataan lapor diri dalam WFRQ, dengan memakai penilaian empat skala Likert 1-4 (rentang 
jawaban mulai dari sangat tidak sesuai hingga sangat sesuai). Contoh item WFRQ adalah "Kesulitan kami meningkatkan kepedulian dan keinginan membantu satu sama lain", "Kami mudah menyesuaikan diri dengan tantangan baru", dan "Kami menunjukkan pengertian, menerima perbedaan, dan menghindari penilaian negatif".

Dalam penelitian ini, koefisien reliabilitas yang dihasilkan oleh WFRQ sebesar .920 dengan corrected item total correlation berkisar antara .035 - .728, kecuali item nomor 12 dan 22 yang memiliki corrected item total correlation di bawah .2. Mempertimbangkan reliabilitas alat ukur ini tergolong baik, maka peneliti tidak menggugurkan kedua item tersebut.

Uji asumsi klasik yang digunakan meliputi uji normalitas dengan Kolmogorov Smirnov dan uji linearitas. Setelah syarat uji asumsi klasik terpenuhi, data dianalisis dengan menggunakan uji regresi sederhana untuk menilai kontribusi variabel prediktor terhadap variabel kriteria.

Tabel 1

Hasil Uji Normalitas

\begin{tabular}{|c|c|c|}
\hline Variabel & K-SZ & Sig.(2-tailed) \\
\hline $\begin{array}{l}\text { Resiliensi Keluarga } \\
\text { dengan Kualitas } \\
\text { Hidup dimensi } \\
\text { Kesehatan Fisik }\end{array}$ & .045 & .200 \\
\hline $\begin{array}{l}\text { Resiliensi Keluarga } \\
\text { dengan Kualitas } \\
\text { Hidup dimensi } \\
\text { Psikologis }\end{array}$ & .066 & .200 \\
\hline $\begin{array}{l}\text { Resiliensi Keluarga } \\
\text { dengan Kualitas } \\
\text { Hidup dimensi } \\
\text { Relasi Sosial }\end{array}$ & .068 & .200 \\
\hline $\begin{array}{l}\text { Resiliensi Keluarga } \\
\text { dengan Kualitas } \\
\text { Hidup dimensi } \\
\text { Lingkungan }\end{array}$ & .056 & .200 \\
\hline
\end{tabular}

Tabel 2

Hasil Uji Linearitas Kualitas Hidup

\begin{tabular}{lcc}
\hline \multicolumn{1}{c}{ Variabel } & F & Sig \\
\hline Dimensi Kesehatan Fisik & 29.297 & .000 \\
Dimensi Psikologis & 18.955 & .000 \\
Dimensi Relasi Sosial & 9.041 & .003 \\
Dimensi Lingkungan & 19.798 & .000 \\
\hline
\end{tabular}

Hasil uji normalitas unstandardized residual antara skor dimensi-dimensi kualitas hidup dengan resiliensi keluarga menunjukkan bahwa data berdistribusi normal $(p>.05)$. Demikian pula, hasil uji normalitas unstandardized residual antara total skor kualitas hidup dengan resiliensi keluarga menunjukkan bahwa data juga berdistribusi normal (tabel 1). Uji linearitas antara skor tiap dimensi kualitas hidup dengan skor resiliensi keluarga menunjukkan data linear (linearity <.05), seperti yang tercantum dalam tabel 2 .

\section{Hasil Penelitian dan Pembahasan}

\section{Gambaran Resiliensi Keluarga dan Kualitas Hidup Remaja Berstatus Sosial Ekonomi Rendah}

Analisis statistik menunjukkan rerata skor resiliensi keluarga sebesar $\mathrm{M}=100.14$ $(\mathrm{SD}=9.77)$. Mayoritas partisipan $(69.23 \%)$ memperoleh skor resiliensi keluarga dalam kategori sedang (tabel 3). Tabel 3 menunjukkan mayoritas partisipan $(69.23 \%)$ menilai keluarganya mempunyai resiliensi dengan kategori sedang. Hal ini berarti partisipan menilai keluarganya telah cukup mampu melakukan coping yang adaptif dan bangkit kembali saat mengalami situasi menekan, meski kemampuan ini belum maksimal. Faktorfaktor yang dapat berkontribusi bagi resiliensi keluarga adalah komunikasi antar anggota keluarga (Pandanwati \& Suprapti, 2012), dukungan sosial (Greef \& Van Der Walt, 2010), harapan (Iriani \& Syafiq, 2017), strategi coping (Greef \& Van Der Walt, 2010), dan koherensi keluarga (Maulidia dkk., 2018; Uswatunnisa dkk., 2019). 
Tabel 3

Kategorisasi Skor Resiliensi Keluarga

\begin{tabular}{lccc}
\hline & Rentang & & \\
Kategorisasi & Skor & f & $\%$ \\
\hline Rendah & $32-90$ & 17 & 13.08 \\
Sedang & $91-110$ & 90 & 69.23 \\
Tinggi & $111-128$ & 23 & 17.69 \\
\hline
\end{tabular}

Tabel 4

Kategorisasi Skor Kualitas Hidup

\begin{tabular}{lcccc}
\hline \multirow{2}{*}{ Dimensi } & \multicolumn{3}{c}{ Rentang } \\
\hline Kesehatan & Rendah & $7-19$ & 25 & $19.2 \%$ \\
Fisik & Sedang & $20-27$ & 85 & $65.4 \%$ \\
& Tinggi & $28-35$ & 20 & $15.4 \%$ \\
Psikologis & Rendah & $6-15$ & 49 & $37.7 \%$ \\
& Sedang & $16-23$ & 79 & $60.8 \%$ \\
\multirow{5}{*}{ Relasi } & Tinggi & $24-30$ & 2 & $1.5 \%$ \\
Sosial & Rendah & $3-6$ & 29 & $22.3 \%$ \\
& Sedang & $7-11$ & 88 & $67.7 \%$ \\
Lingkungan & Tinggi & $12-15$ & 13 & $10 \%$ \\
& Rendah & $8-19$ & 27 & $20.8 \%$ \\
& Sedang & $20-29$ & 85 & $65.4 \%$ \\
& Tinggi & $30-40$ & 18 & $13.8 \%$ \\
\hline
\end{tabular}

Tabel 5

Hasil Uji Korelasi

\begin{tabular}{lcc}
\hline \multicolumn{1}{c}{ Variabel } & r & Sig (2-tailed) \\
\hline $\begin{array}{l}\text { Resiliensi Keluarga } \\
\text { dengan Kualitas Hidup } \\
\text { dimensi Kesehatan Fisik }\end{array}$ & .404 & .000 \\
& .352 & .000 \\
$\begin{array}{l}\text { Resiliensi Keluarga } \\
\text { dengan Kualitas Hidup }\end{array}$ & & \\
dimensi Psikologis & .264 & .002 \\
$\begin{array}{l}\text { Resiliensi Keluarga } \\
\text { dengan Kualitas Hidup } \\
\text { dimensi Relasi Sosial }\end{array}$ & & \\
$\begin{array}{l}\text { Resiliensi Keluarga } \\
\text { dengan Kualitas Hidup } \\
\text { dimensi Lingkungan }\end{array}$ & .338 & .000 \\
\hline
\end{tabular}

Analisis data menunjukkan rerata skor kualitas hidup untuk dimensi kesehatan fisik adalah $\mathrm{M}=23.32(\mathrm{SD}=4.23)$, dimensi psikologis $\mathrm{M}=19.09(\mathrm{SD}=3.83)$, dimensi relasi sosial sebesar $\mathrm{M}=8.41(\mathrm{SD}=2.36)$, dan dimensi lingkungan $\mathrm{M}=24.22$ ( $\mathrm{SD}=$ 5.31). Lebih lanjut, peneliti melakukan kategorisasi skor kualitas hidup berdasarkan rumus Azwar (2010), dimana mayoritas partisipan menilai masing- masing dimensi kualitas hidup berada pada kategori sedang, yakni dimensi kesehatan fisik sebanyak $65.39 \%$ dari keseluruhan partisipan, dimensi psikologis sebanyak $60.77 \%$, dimensi relasi sosial sebanyak $67.69 \%$, dan dimensi lingkungan sebanyak $65.38 \%$. Data kategorisasi selengkapnya dapat dilihat pada tabel 4 .

Berdasarkan tabel 4, terlihat bahwa mayoritas partisipan penelitian $(60.77 \%$ $67.69 \%$ ) ini mempersepsikan dirinya memiliki dimensi-dimensi kualitas hidup dalam kategori sedang. Hal ini mengindikasikan partisipan merasa cukup puas dengan aspek-aspek kehidupan, yang meliputi kesehatan fisik, psikologis, relasi sosial, dan lingkungan. Variabel yang mungkin berkontribusi pada kualitas hidup adalah coping (Martindale dkk., 2016), interpretasi yang negatif terhadap situasi sulit yang dialami (Cappe dkk., 2018), dukungan sosial (Cappe dkk., 2018; Sanchaya dkk., 2018), depresi (Teles dkk., 2018), pola asuh (Petito \& Cummins, 2000), serta pemberdayaan keluarga (Minooei dkk., 2016).

\section{Hubungan Resiliensi Keluarga dengan Dimensi-dimensi Kualitas Hidup}

Uji korelasi dengan Pearson Product Moment dilakukan sebelum peneliti melaksanakan uji regresi sederhana. Tujuan uji korelasi adalah mengetahui hubungan antar variabel, dalam hal ini resiliensi keluarga dengan dimensi-dimensi kualitas hidup. Hasil analisis membuktikan resiliensi keluarga memiliki hubungan positif yang signifikan dengan dimensidimensi kualitas hidup sebesar .264 - .404 $(p=.000$ dan .002). Artinya, semakin tinggi resiliensi keluarga yang dipersepsikan partisipan, maka semakin tinggi kualitas hidup pada dimensi kesehatan fisik, psikologis, relasi sosial, dan lingkungan, yang juga dipersepsikan oleh partisipan. Kekuatan hubungan variabel-variabel tersebut adalah rendah hingga sedang ( $r=$ $.264-.404)$. 
Resiliensi Keluarga sebagai Prediktor Dimensi-dimensi Kualitas Hidup

Hasil uji hipotesis menunjukkan resiliensi keluarga memiliki pengaruh positif yang signifikan terhadap dimensidimensi kualitas hidup pada remaja dengan status sosial ekonomi rendah yang menjadi partisipan penelitian ini, yakni dimensi kesehatan fisik, psikologis, relasi sosial, dan lingkungan, dengan besar kontribusi antara $7 \%$ hingga $16.4 \%$ (tabel 6 ).

Dari hasil analisis data diketahui terdapat peran signifikan dari resiliensi keluarga terhadap dimensi-dimensi kualitas hidup pada partisipan penelitian, dengan kontribusi antara 7\% hingga $16.4 \%$ ( $p=.000$ dan .002). Hasil ini mendukung temuan penelitian Openshaw (2011), yang menyatakan resiliensi keluarga berkontribusi pada kualitas hidup penyandang disabilitas. Selain itu, temuan penelitian ini juga memperkuat teori ekologi dari Bronfenbrenner (1979, dalam Gamayanti, 2014), yakni adanya faktor lingkungan terdekat atau mikrosistem (salah satunya keluarga) yang berperan bagi perkembangan individu. Keluarga yang resilien memaknai dan menilai situasi sulit secara positif (Walsh, 2012), yang mana hal ini akan memengaruhi bagaimana remaja menginterpretasikan risiko yang mungkin didapat dari situasi sulit yang dialami dari perspektif yang positif pula. Maguire dkk. (2017) menemukan bahwa interpretasi terhadap risiko memengaruhi kualitas hidup.

Tabel 6

Hasil Uji Regresi Sederhana: Pengaruh Resiliensi Keluarga terhadap Dimensi-dimensi Kualitas Hidup

\begin{tabular}{lcccc}
\hline \multicolumn{1}{c}{ Dimensi } & $\begin{array}{c}R- \\
\text { Square }\end{array}$ & $\mathrm{F}$ & $\mathrm{Sig}$ & $\begin{array}{c}\text { Persamaan } \\
\text { Regresi }\end{array}$ \\
\hline Kesehatan & .164 & 25.019 & .000 & $\mathrm{Y}=40.784+$ \\
Fisik & & & & $174 \mathrm{X}$ \\
Psikologis & .124 & 18.151 & .000 & $\mathrm{Y}=32.879+$ \\
& & & & $138 \mathrm{X}$ \\
Relasi Sosial & .070 & 9.573 & .002 & $\mathrm{Y}=14.782+$ \\
& & & & $64 \mathrm{X}$ \\
Lingkungan & .114 & 16.477 & .000 & $\mathrm{Y}=42.605+$ \\
& & & & $181 \mathrm{X}$ \\
\hline
\end{tabular}

Temuan penelitian ini juga mengindikasikan bahwa terdapat $83.6 \%$ hingga $93 \%$ faktor lain, selain resiliensi keluarga, yang berkontribusi pada dimensidimensi kualitas hidup. Hasil-hasil penelitian terdahulu menunjukkan terdapat sejumlah faktor yang berkorelasi atau berkontribusi terhadap kualitas hidup yakni coping (Martindale dkk., 2016), interpretasi negatif terhadap situasi sulit yang dialami (Cappe dkk., 2018), dukungan sosial (Cappe dkk., 2018; Sanchaya dkk., 2018), pola asuh (Petito \& Cummins, 2000), dan pemberdayaan keluarga (Minooei dkk., 2016). Berbagai faktor tersebut meliputi faktor personal maupun keluarga, selaku lingkungan terdekatnya. Hal ini mengindikasikan, perlu ada sinergi antara individu dengan lingkungan di sekitarnya dalam mewujudkan kualitas hidup.

Secara spesifik, dalam penelitian ini resiliensi keluarga memberikan sumbangan efektif terhadap kualitas hidup dimensi kesehatan fisik sebesar $16.4 \%(\mathrm{~F}=25.019$, $\mathrm{p}=.000)$. Dimensi kesehatan fisik terkait dengan kapasitas individu untuk melakukan rutinitas sehari-hari, penggunaan obat dan alat medis, vitalitas dan keletihan, pergerakan, rasa sakit dan ketidaknyamanan, serta kinerja (Adeyeye dkk., 2014). Keluarga yang dapat menghadapi situasi sulit dengan adaptif, tidak merasa tertekan dalam menjalani kehidupan (Walsh, 2012), sehingga akan memengaruhi atau mengajarkan anggota keluarganya untuk tidak merasa tertekan pula.

Dalam kaitannya dengan dimensi kesehatan fisik pada kualitas hidup, kondisi individu yang terbebas dari stres akan meningkatkan sistem imun dan melindunginya dari gangguan kesehatan fisik (Khalil dkk., 2020). Ini mendukung pernyataan Lewitus dan Schwartz (2009), yakni resiliensi dapat menjadi faktor protektif terhadap penyakit kronis, disabilitas, kesehatan fisik individu, serta individu dapat memiliki sistem imun yang baik. Selain itu, keluarga yang resilien 
memiliki kemampuan pemecahan masalah kolaboratif (Walsh, 2012) yang dapat digunakan untuk mencari upaya dalam memastikan anggota keluarga tetap sehat dan terhindar dari penyakit di tengah keterbatasan sumber daya.

Secara spesifik, dalam penelitian ini resiliensi keluarga memberikan sumbangan efektif terhadap kualitas hidup dimensi psikologis sebesar $12.4 \%(\mathrm{~F}=18.151, \mathrm{p}=$ .000). Dimensi psikologis terkait dengan keadaan mental individu (Adeyeye dkk., 2014). Keluarga yang resilien memiliki kohesivitas antar anggotanya, mengekspresikan emosi secara terbuka dan tanpa dihakimi, serta saling memberikan dukungan sosial (Walsh, 2012). Huber dkk. (2010) mengemukakan dukungan sosial yang disediakan keluarga untuk anggotanya dapat berupa dukungan emosional, yakni adanya sikap saling peduli yang dikomunikasikan dalam keluarga dan juga dukungan terhadap harga diri. Hal ini dapat membuat mental individu menjadi lebih sehat, yang pada akhirnya meningkatkan kualitas hidup dimensi psikologis. Selain itu, dukungan yang diperoleh individu dari keluarga yang resilien dapat menimbulkan perasaan puas, yang kemudian meningkatkan kualitas hidup (Cappe dkk., 2018). Sebuah temuan penelitian juga menunjukkan bahwa dukungan dari keluarga berkontribusi signifikan terhadap kualitas hidup individu (Sanchaya dkk., 2018).

Secara spesifik, dalam penelitian ini resiliensi keluarga memberikan sumbangan efektif terhadap kualitas hidup dimensi relasi sosial sebesar 7\% ( $\mathrm{F}=9.573, \mathrm{p}=$ .000). Dimensi relasi sosial terkait dengan hubungan individu dengan orang lain yang meliputi relasi personal, dukungan dari lingkungan sekitar, perilaku seksual, juga komunikasi dengan orang lain (Adeyeye dkk., 2014). Keluarga mengajarkan anak bagaimana berinteraksi dan memelihara relasi sosial (Grenwald-Mayes, 2002). Dengan demikian, anak mengetahui dan mampu untuk menjalin hubungan sosial yang sehat dengan orang-orang di sekitar. Kompetensi dalam mengembangkan relasi sosial ini memungkinkan anak untuk memperoleh dukungan sosial dari lingkungannya (non keluarga), yang mana adanya dukungan sosial ini dapat meningkatkan kualitas hidup khususnya dimensi sosial.

Secara spesifik, dalam penelitian ini resiliensi keluarga memberikan sumbangan efektif terhadap kualitas hidup dimensi lingkungan sebesar $11.4 \%(\mathrm{~F}=16.477, \mathrm{p}=$ $.000)$. Dimensi lingkungan terkait dengan tempat tinggal seseorang, yaitu situasi, ketersediaan hunian untuk melakukan aktivitas, fasilitas yang dapat membantu kehidupan, keuangan, kemandirian, rasa aman, hiburan dan kesempatan menikmati waktu luang (Adeyeye dkk., 2014). Saat menghadapi situasi krisis, keluarga yang resilien dapat mengembangkan keterampilan kolaboratif yang meliputi keterampilan mengantisipasi risiko dan pemecahan masalah (Saltzman dkk., 2013). Dengan kemampuan ini, keluarga dapat mengidentifikasikan potensi masalah yang ditimbulkan oleh lingkungan yang tidak sehat dan merumuskan solusi untuk mengatasi masalah tersebut. Dengan demikian, kualitas hidup remaja (sebagai anggota keluarga) dalam dimensi lingkungan tetap dapat terjaga. Selain itu, keluarga yang resilien memiliki akses dan dapat memanfaatkan sumber daya yang dimiliki (Saltzman dkk., 2013). Sumber daya ini dapat berupa sesuatu yang tangible, psikososial, maupun berbagai layanan yang terdapat di masyarakat seperti layanan pendidikan, kesehatan, keagamaan, dan sebagainya (Saltzman dkk., 2013; Ungar, 2012). Keluarga dengan status sosial ekonomi rendah mungkin saja kurang atau tidak memiliki sumber daya material atau ekonomi, tapi bisa saja mereka memiliki akses terhadap sumber daya lainnya tersebut di atas, yang dapat membantunya mengatasi masalah yang timbul dari lingkungan sekitar yang tidak kondusif atau tidak ideal. Dengan 
demikian, remaja selaku anggota keluarga, dapat terhindar dari risiko negatif yang diperoleh dari situasi lingkungan yang tidak kondusif sehingga membuat kualitas hidupnya menjadi lebih baik.

Penelitian ini mengungkap tidak terdapat perbedaan signifikan pada kualitas hidup partisipan berdasarkan jenis kelamin, baik pada dimensi kesehatan fisik $(\mathrm{F}=1.329 ; \quad \mathrm{p}=.210)$, dimensi psikologis $(\mathrm{F}=.062 ; \mathrm{p}=.275)$, dimensi hubungan sosial $(\mathrm{F}=.257 ; \mathrm{p}=.865)$, maupun dimensi lingkungan $(\mathrm{F}=1.049 ; \mathrm{p}=.232)$. Temuan ini berbeda dari temuan-temuan penelitian sebelumnya, dimana Indrayani dan Ronoatmodjo (2018) maupun Gibney dkk. (2015) menemukan bahwa terdapat perbedaan kualitas hidup ditinjau dari jenis kelamin. Dalam penelitian ini tidak ditemukan pula perbedaan kualitas hidup ditinjau dari penyakit kronis, baik dalam dimensi kesehatan fisik $(\mathrm{F}=.000 ; \mathrm{p}=.354)$, dimensi psikologis $(\mathrm{F}=.213 ; \mathrm{p}=.790)$, dimensi hubungan sosial $(\mathrm{F}=.257 ; \mathrm{p}=.865)$, dimensi lingkungan $(\mathrm{F}=.460 ; \mathrm{p}=.285)$. Hasil penelitian ini berbeda dari temuan penelitian sebelumnya (Pradono dkk., 2009). Peneliti menduga bahwa fasilitas layanan kesehatan dan layanan pendampingan di Jakarta telah tersedia dan mudah diakses oleh warga dengan status sosial ekonomi rendah, sehingga mereka cepat tertangani ketika mengalami penyakit kronis, yang pada akhirnya tidak memengaruhi kualitas hidupnya.

Uji statistik membuktikan tidak ditemukan perbedaan signifikan resiliensi keluarga bila ditinjau dari status pernikahan orang tua $(\mathrm{F}=.749 ; \mathrm{p}=.470)$. Hasil ini mendukung penelitian sebelumnya yang dilakukan oleh Mashego dan Taruvinga (2014) yang mengatakan terdapat perbedaan resiliensi keluarga ditinjau dari status pernikahan. Sementara itu, terdapat perbedaan signifikan pada resiliensi keluarga berdasarkan tingkat pendidikan $(\mathrm{F}=.903 ; \mathrm{p}=$. 000). Temuan tersebut memperkuat hasil penelitian sebelumnya yang dilakukan Bradley dan Hojjat (2016), yakni semakin tinggi tingkat pendidikan individu, maka semakin resilien pula keluarganya. Hal ini disebabkan pendidikan yang lebih tinggi memungkinkan para anggota keluarga untuk memperoleh pengetahuan dan keterampilan pemecahan masalah (problem solving skill) dan mencari cara untuk mengakses sumber daya yang dibutuhkan guna mengatasi situasi sulit, yang merupakan ciri keluarga resilien (Walsh, 2012).

Masih terdapat beberapa keterbatasan dalam penelitian ini. Pertama, resiliensi keluarga dilihat melalui satu sudut pandang anggota keluarga; dalam hal ini remaja dengan status sosial ekonomi rendah yang menjadi partisipan penelitian ini. Artinya, bisa saja individu memberikan penilaian yang subyektif mengenai resiliensi keluarganya. Kedua, pengukuran kualitas hidup dilakukan berdasarkan persepsi partisipan semata, dan tidak menggunakan indikator yang lebih obyektif. Penelitian selanjutnya dapat menggunakan pengukuran resiliensi keluarga maupun kualitas hidup secara lebih obyektif. Ketiga, penelitian ini hanya berfokus pada kontribusi resiliensi keluarga terhadap kualitas hidup, dan tidak meneliti variabelvariabel yang memperantarai hubungan keduanya. Teori sistem keluarga menyebutkan dinamika yang terjadi dalam keluarga dapat memengaruhi kondisi psikologis individu (Lestari, 2012).

Penelitian-penelitian sebelumnya mengindikasikan faktor psikologis individual tersebut merupakan faktor yang juga berkontribusi signifikan terhadap kualitas hidup (Kawitri dkk., 2020; Wijayanti dkk., 2020; Rachmawati dkk., 2019). Dengan demikian, kami menduga terdapat faktor individual yang mungkin memediasi pengaruh resiliensi keluarga terhadap kualitas hidup. Penelitian selanjutnya dapat meneliti faktor-faktor yang mungkin memediasi hubungan antara resiliensi keluarga dengan kualitas hidup. Kemudian, sumbangan efektif yang dihasilkan resiliensi keluarga terhadap 
masing-masing dimensi kualitas hidup hanya sebesar $7 \%$ hingga $16.4 \%$. Artinya, masih terdapat $83.6 \%$ hingga $93 \%$ faktor lainnya yang berpengaruh terhadap kualitas hidup. Penelitian berikutnya dapat mengeksplorasi variabel-variabel yang belum teridentifikasi tersebut, dalam hubungannya dengan kualitas hidup.

Keterbatasan berikutnya, status sosial ekonomi rendah dalam penelitian ini diukur secara subyektif, yakni dengan meminta partisipan (yang merupakan remaja, dan berstatus sebagai anak dalam keluarga) menuliskan jumlah penghasilan orang tua/ keluarga mereka dalam satu bulan dan mengeliminasi mereka yang keluarganya berpenghasilan di atas batas yang ditetapkan Badan Pusat Statistik (BPS). Ketidakakuratan partisipan dalam menilai jumlah penghasilan keluarganya bisa saja terjadi. Dalam penelitian selanjutnya, dapat menggunakan data yang lebih obyektif, misalnya data resmi dari pejabat (RT, RW) di lingkungan tempat tinggal partisipan.

\section{Simpulan}

Perolehan penelitian ini mengungkapkan adanya sumbangan signifikan dari resiliensi keluarga terhadap tiap-tiap dimensi kualitas hidup remaja berstatus sosial ekonomi rendah sebesar $7 \%$ hingga $16.4 \%$. Pengaruh yang dihasilkan bersifat positif, artinya semakin resilien keluarga partisipan, maka semakin baik kualitas hidupnya. Hasil penelitian ini mengindiksikan kualitas hidup tidak semata-mata dipengaruhi faktor personal saja seperti yang selama ini diteliti, namun juga kondisi keluarganya. Hal ini memperluas pemahaman tentang kualitas hidup dengan menyertakan pentingnya kontribusi keluarga sebagai lingkungan sosial terdekat individu.

Mempertimbangkan pentingnya keluarga yang resilien untuk mewujudkan kualitas hidup yang baik pada remaja berstatus sosial ekonomi rendah, maka masyarakat, pemerintah, dan pihak-pihak lainnya dapat memfasilitasi keluarga sebagai unit masyarakat terkecil untuk memiliki kemampuan adaptasi dengan situasi sulit, memaknai situasi secara positif, mampu mengembangkan harapan, memiliki relasi yang kohesif dan suportif antar anggota keluarga, serta memiliki kemampuan pemecahan masalah secara kolaboratif, yang merupakan karakteristik keluarga yang resilien.

\section{Daftar Pustaka}

Adeyeye, O., Ogunleye, O., \& Coker, A. (2014). Factors influencing quality of life and predictors of low quality of life scores in patient on treatment for pulmonary tuberculosis: A cross sectional study. Journal of Public Health in Africa, 5(2), 88-92. https://dx.doi.org/10.4081\%2Fjphia.20 14.366

Aisyah, P., \& Listiyandini, R. A. (2015, Oktober 20-21). Peran resiliensi dalam memprediksi kualitas hidup ibu yang tinggal di bantaran sungai Ciliwung (Proceeding). Seminar Ilmiah Nasional PESAT, Depok, Jawa Barat, Indonesia. https://ejournal.gunadarma.ac.id/index. php/pesat/article/view/1339/1193

Ali, S., \& Malik, J. A. (2015). Consistency of prediction across generation: Explaining quality of life by family functioning and health promoting behaviors. Qual Life Res, 24(9), 21052112. https://doi.org/10.1007/s11136015-0942-6

Archentari, K. A., Gasela, V., Nuriyyatiningrum, N. A., \& Iskandarsyah, A. (2017). Harga diri dan kualitas hidup pada pasien chronic kidney disease yang menjalani hemodialisa. Jurnal Psikologi, 16(2), 138-146. https://doi.org/10.14710/jp.16.2.138146

Azwar, S. (2010). Penyusunan skala psikologi. Pustaka Pelajar.

Azwar, S. (2016). Konstruksi tes kemampuan kognitif. Pustaka Pelajar. 
Badan Pusat Statistik (BPS). (2019, Januari 1). Profil kemiskinan di Indonesia september 2018. https://www.bps.go.id/pressrelease/201 9/01/15/1549/persentase-pendudukmiskin-pada-september-2018-sebesar9-66-persen.html

Bradley, J. M., \& Hojjat, M. (2016). A model of resilience and marital satisfaction. The Journal of Social Psychology, 157(5), 588-601. https://doi.org/10.1080/00224545.2016 .1254592

Caliskan, H., Erturk, N., Kutukcu, E. C., Arikan, H., Yagli, N. V., Saglam, M., Firat, H., Ardic. S., Ince, D. I., \& Ege, M. Y. (2019). The relationship between the physical activity level and fatigue perception, quality of life, and psychological status in patients with obstructive sleep apnea syndrome. Journal of Turkish Sleep Medicine, 6, 1-6.

http://dx.doi.org/10.4274/jtsm.galenos. 2019.28247

Cappe, E., Poirier, N., Sankey, C., Belzil, A., \& Dionne, C. (2018). Quality of life French Canadian parents raising a child with autism spectrum disorder and effects of psychosocial factors. Qual Life Res, 27(4), 955-967. https://doi.org/10.1007/s11136-0171757-4

Caron, J. (2012). Predictors of quality of life in economically disadvantaged populations in Montreal. Social Indicator Research, 107(3), 411-427. http://dx.doi.org/10.1007/s11205-0119855-0

Chachamovich, J. R., Chachamovich, E., Ezer, H., Fleck, M. P., Knauth, D., \& Passos, E. P. (2010). Investigating quality of life and health related quality of life in infertility: A systematic review. Journal of Psychosomatics Obstetrics \& Gynecology, 31(2), 101110.

https://doi.org/10.3109/0167482x.2010 .481337
Desnauli, E., Nursalam, \& Efendi, F. (2011). Indikator kualitas hidup pasien gagal kronis yang menjalani hemodialisa berdasarkan strategi koping. Jurnal Ners, 6(2), 187-191. http://dx.doi.org/10.20473/jn.v6i2.399 0

Gibb, J., Rix, K., Wallace, E., Fitzsimons, E., \& Mostafa, T. (2016). Poverty and children's personal and social relationships. National Children's Bureau.

Gibney, S., Delaney, L., Codd, M. B., \& Fahey, T. (2015). Lifetime childlessness, depressive mood and quality of life among older Europeans. Social Indicators Research, 130(1), 305-323. https://doi.org/10.1007/s11205-0151177-1

Gravetter, F. J., \& Forzano, L. A. (2015). Research methods for the behavioral sciences. Cengage Learning.

Gamayanti, W. (2014). Usaha bunuh diri berdasarkan teori ekologi Bronfenbrenner. Psympathic: Jurnal Ilmiah Psikologi, 1(2), 204-230. https://doi.org/10.15575/psy.v1i2.478

Gamayanti, W., \& Hidayat, I. N. (2019). Marah dan kualitas hidup orang yang mengalami psikosomatik. Jurnal Psikologi, 18(2), 177-186. https://doi.org/10.14710/jp.18.2.177186

Greef, A. P., \& Van Der Walt, K. J. (2010). Resilience in families with autistic child. Education and Training in Autism and Developmental Disabilities, 45(3), 347-355.

Grenwald-Mayes, G. (2002). Relationship between current quality of life and family of origin dynamics for college students with attentiondeficit/hyperactivity disorder. Journal of Attention Disorder, 5(4), 211-222. https://doi.org/10.1177/108705470100 500403

Hidayat, I. N., \& Gamayanti, W. (2020). Dengki, bersyukur, dan kualitas hidup 
orang yang mengalami psikosomatik. Psympathic: Jurnal Ilmiah Psikologi, $7(1)$, 79-92. https://doi.org/10.15575/psy.v7i1.6027

Huber, C. H., Navarro, R. L., Womble, M. W., \& Mumme, F. L. (2010). Family resilience and midlife marital satisfaction. The Family Journal Counseling and Therapy for Couples and Families, 18(2), 136-145. https://psycnet.apa.org/doi/10.1177/10 66480710364477

Indrayani, \& Ronoatmodjo, S. (2018). Faktor-faktor yang berhubungan dengan kualitas hidup lansia di desa Cipasung kabupaten Kuningan tahun 2017. Jurnal Kesehatan Reproduksi, 9(1), 69-78. https://doi.org/10.22435/kespro.v9i1.8 92.69-78

Iriani, L. P., \& Syafiq, M. (2017). Gambaran hope pada seseorang penyandang tunarungu wicara yang berprestasi. Character : Jurnal Psikologi Pendidikan, 4(3), 1-6.

Khalil, A. I., Nasr, R. E., \& Enar, R. E. (2020). Relationship between stress, immune system, and pandemics of coronaviruses' Covid 19: Updates narrative review. European Journal of Molecular and Clinical Medicine., 7(10), 995-1008.

Kawitri, A. Z., Listiyandini, R. A., \& Rahmatika, R. (2020). Peran self compassion terhadap dimensi-dimensi kualitas hidup kesehatan pada remaja panti asuhan. Psympathic: Jurnal Ilmiah Psikologi, 7(1), 01-18. https://doi.org/10.15575/psy.v7i1.4406

Kim, Y., \& Hagquist, C. (2018). Trends in adolescent mental health during economic upturns and downturns: A multilevel analysis of Swedish data 1988-2008. Journal of Epidemiology \& Community Health, 72(2), 101-108. https://doi.org/10.1136/jech-2017209784

Lestari, S. (2012). Psikologi keluarga. Kencana Prenada Media Group.
Lewitus, G. M., \& Schwartz, M. (2009). Behavioral immunization: Immunity to self antigens contributes to psychological stress resilience. Molecular Psychiatry, 14(5), 532-536. https://doi.org/10.1038/mp.2008.103

Liputo, S. (2014). Distres psikologik dan disfungsi sosial di kalangan masyarakat miskin kota Malang. Jurnal Sains dan Praktik Psikologi, 2(3), 286-295.

Lovie-Toon, Y. G., Chang, A. B., Newcombe, P. A., Vagenas, D., Anderson-James, S., Drescher, B. J., Otim, M. E., \& O'Grady, K. A. (2018). Longitudinal study of quality of life among children with acute respiratory infection and cough. Quality of Life Research, 27(4), 891-903. https://doi.org/10.1007/s11136-0171779-y

Maguire, R., Hanly, P., Drummond, F. J., Gavin, A., \& Sharp, L. (2018). Expecting the worst? The relationship between retrospective and prospective appraisals of illness on quality of life in prostate cancer survivors. PsycoOncology, 27(4), 1237-1243. https://doi.org/10.1002/pon.4660

Martindale, S. L., Morissette, S. B., Kimbrel, N. A., Meyer, E. C., Kruse, M. I., Gulliver, S. B., \& Dolan, S. L. (2016). Neuropsychology functioning, coping, and quality of life among returning war veterans. Rehabil Psychol, 61(3), 231-239. https://dx.doi.org/10.1037/rep0000076

Mashego, T. B., \& Taruvinga, P. (2014). Family resilience factors influencing teenager adaptation following parental divorce in Limpo province South Africa. Journal of Psychology, 5(1), 19-34.

https://doi.org/10.1080/09764224.2014 .11885502

Maulidia, F. N., Kinanthi, M. R., Fitria, N., \& Permata, A. S. (2018). Peran koherensi terhadap kelentingan keluarga yang memiliki anak dengan 
spektrum autistik. Jurnal Ilmu Keluarga dan Konsumen, 11(1), 13-24. Minooei, M. S., Ghazavi, Z., Abdeyazdan, Z., Gheissari, A., \& Hemati, Z. (2016). The effect of the family empowerment model on quality of life in children with chronic renal failure: Children's and parents' view. Nephrourol Mon, $8(4)$, https://dx.doi.org/10.5812/numonthly.3 6854

Mufarrohah, L., \& Kinanthi, M. R. (2020, Nopember 16-20). Peran resiliensi keluarga terhadap kualitas hidup individu dewasa muda yang tinggal di Jakarta di masa pandemi. Konferensi Konsorsium Psikologi Ilmiah Nusantara, Jakarta (Daring), Indonesia.

Newacheck, P. W., Hung, Y. Y., Park, M. J., Brindis, C. D., \& Irwin, C. E. (2003). Disparities in adolescent health and health care: Does socioeconomic status matter? Health Services Research, 38(5), 1235-1252. https://dx.doi.org/10.1111/14756773.00174

Nikmah, M., \& Mauliza. (2018). Kualitas hidup penderita talasemia berdasarkan instrument pediatric quality of life inventory 4.0 generic core scale di ruang rawat anak rumah sakit umum cut meutia Aceh Utara. Sari Pediatri, 20(1), 11-16. https://dx.doi.org/10.14238/sp20.1.201 8.11-6

Oktowaty, S., Setiawati, E. P., \& Arisanti, N. (2018). Hubungan fungsi keluarga dengan kualitas hidup pasien penyakit kronis degeneratif di fasilitas kesehatan tingkat pertama. Jurnal Sistem Kesehatan, 4(1), 1-6. https://doi.org/10.24198/jsk.v4i1.1918 0

Openshaw, P. K. (2011). The relationship between family functioning, family resilience, and quality of life among vocational rehabilitation clients (Disertasi tidak diterbitkan). Utah State University.
Pandanwati, I. S., \& Suprapti, V. (2012). Resiliensi keluarga pada pasangan dewasa madya yang tidak memiliki anak kandung. Jurnal Psikologi Pendidikan dan Perkembangan, 1(3), $1-8$.

Pane, J., \& Saragih, I. S. (2020). The relationship of resilience and quality of life with chronic disease who undergoing haemodialysis in Rasyda kidney hospital Medan. Jurnal Ilmu Keperawatan (Journal of Nursing and Science), $\quad 8(1), \quad 10-14$. http://dx.doi.org/10.21776/ub.jik.2020. 008.01 .2

Patty, S. R., \& Nugroho, F. (2019). Kemiskinan dan malnutrisi pada anak balita dalam keluarga nelayan di wilayah pesisir kota Serang. Empati, 8(2), 109-125.

Petito, F., \& Cummins, R. A. (2000). Quality of life in adolescence: The role of perceived control, parenting style, and social support. Behavior Change, 17(3), 196-207.

Pradono, J., Hapsari, D., \& Sari, P. (2009). Kualitas hidup penduduk Indonesia menurut international classification of functioning, disability, and health (ICF) dan faktor-faktor yang memengaruhinya. Buletin Penelitian Kesehatan, 3, 1-10.

Purba, F. J., Hunfeld, J. A., Iskandarsyah, A., Fitriana, T. S., Sadarjoen, S. S., Passchier, J., \& Bussbach, J. J. (2018). Quality of life of the Indonesian general population: Test-retest reliability and population norms of the EQ-5D-5L and WHOQOL-BREF. Plos One, 13(5), 1-20. https://doi.org/10.1371/journal.pone.01 97098

Rachmawati, B. D., Listiyandini, R. A., \& Rahmatika, R. (2019). Resiliensi psikologis dan pengaruhnya terhadap kualitas hidup terkait kesehatan pada remaja di panti asuhan. Analitika, 11(1), 
https://doi.org/10.31289/analitika.v11i 1.2314

Restiyani, P., Fitriyah, \& Astrika, L. (2013). Aksesibilitas masyarakat miskin dalam memperoleh pelayanan kesehatan (Studi kasus di kawasan kampung Tambak Mulyo kelurahan Tanjung Mas Semarang). Journal of Politic and Government Studies, 2(3), 186-195.

Rohmah, A. I., Purwaningsih, \& Bariyah, K. (2012). Kualitas hidup lanjut usia. Jurnal Keperawatan, 3(2), 120-132. https://doi.org/10.22219/jk.v3i2.2589

Saltzman, W. R., Pynoos, R. S., Lester, P., Layne, C. M., \& Beardslee, W. R. (2013). Enhancing family resilience through family narrative coconstruction. Clin Child Fam Psychol Rev, 16, 294-310. https://doi.org/10.1007/s10567-0130142-2

Sanchaya, K. P., Sulistiowati, N. D., \& Yanty, N. E. (2018). Hubungan dukungan keluarga dengan kualitas hidup orang dengan gangguan jiwa. Jurnal Ilmu Keperawatan Jiwa, 1(2), 87-92. https://doi.org/10.32584/jikj.v1i2.151

Shek, D., \& Tsui, P. F. (2012). Family and personally adjustment of economically disadvantaged Chinese adolescents in Hong Kong. The Scientifc World Journal, $\quad 1, \quad 1-8$. http://dx.doi.org/10.1100/2012/142689

Suparto. (2014). Evaluasi pemukiman dan perumahan kumuh berbasis lingkungan di kelurahan Kalibanteng Kidul kota Semarang. Pawiyatan, 21(1), 32-42.

Taylor, R. D. (2010). Risk and resilience in low income African American families: Moderating effects of kinship social support. Cultural Diversity and Ethnic Minority Psychology, 16(3), 344-351.

https://doi.org/10.1037/a0018675

Teles, F., de Albuquerque, A. L., Lins, I. K., Medrado, P. C., \& Costa, A. P. (2018). Quality of life and depression in haemodialysis patients. Psychological, Health, and Medicine, 23(9), 1069-1078. https://doi.org/10.1080/13548506.2018 .1469779

Ungar, M. (2012). Social ecologies and their contribution to resilience. Dalam M. Ungar (Ed.), The social ecology of resilience: A handbook of theory and practice (hal. 13-31). Springer.

Uswatunnisa, A., Brebahama, A., \& Kinanthi, M. R. (2019). Peran family sense of coherence terhadap resiliensi keluarga yang memiliki anak tunanetra ditinjau dari perspektif ibu. Jurnal Psikogenesis, $\quad 7(2), \quad$ 201-214. https://doi.org/10.24854/jps.v7i2.1132

Walsh, F. (2012). Facilitating family resilience: Relational resources for positive youth development in condition of adversity. Dalam M. Ungar (Ed.), The social ecology of resilience: A handbook of theory and practice (hal. 173-186). Springer.

Wandasari, W. (2012). Hubungan antara resiliensi keluarga dan koherensi keluarga pada mahasiswa yang berasal dari keluarga miskin (Skripsi tidak diterbitkan). Universitas Indonesia, Fakultas Psikologi

Wijayanti, S., Rahmatika, R., \& Listiyandini, R. A. (2020). Kontribusi kebersyukuran dalam peningkatan kualitas hidup kesehatan pada remaja di panti asuhan. Psycho Idea, 18(1), 33-44.

http://dx.doi.org/10.30595/psychoidea. v18i1.4123

Yuwindry, I., Wiedyaningsih, C., \& Widodo, G. P. (2016). Pengaruh pengetahuan terhadap kualitas hidup dengan kepatuhan penggunaan obat sebagai variabel antara pada DM. Jurnal Manajemen dan Pelayanan Farmasi, 6(4), 249-254. https://doi.org/10.22146/jmpf.353 
Psympathic, Jurnal Ilmiah Psikologi Juni 2021, Vol.8, No.1, Hal. : 31-46 